\title{
The Role of Endogenous Adenosine in a Poststimulation Increase in the Acetylcholine Content of a Sympathetic Ganglion
}

\author{
A. Tandon and B. Collier \\ Department of Pharmacology and Therapeutics, McGill University, Montreal, Quebec, Canada
}

Previous experiments showed that exposure of sympathetic ganglia to exogenous adenosine increased acetylcholine (ACh) content and its subsequent release. This effect was not mediated through extracellular adenosine receptors, but at an intracellular site following its uptake through nitrobenzylthioinosine (NBTI)-resistant nucleoside transporters. We postulated that endogenous adenosine may play a role in modulating synaptic transmission in the superior cervical ganglion. The present study tested whether adenosine is involved in the activation of ACh synthesis that occurs during a rest period following prolonged presynaptic tetanic activity. Conditioning of ganglia with high-frequency stimulation $(15 \mathrm{~Hz})$ for $\mathbf{4 5}$ min followed by a $15 \mathrm{~min}$ rest increased their ACh content by $\mathbf{4 5} \%$. The appearance of this "rebound ACh" showed sensitivity to nucleoside transport inhibitors; it was prevented by dipyridamole, but not by NBTI or meclonazepam, and it was reduced in the presence of RO 11-3624, suggesting an involvement of NBTI-resistant transporters. The effect of dipyridamole was specific for the synthesis of rebound $\mathrm{ACh}$ in that it did not inhibit $\mathrm{ACh}$ release or $\mathrm{ACh}$ synthesis during stimulation. The inhibitory action of dipyridamole on the synthesis of rebound $\mathrm{ACh}$ was not evident if it was present only during the tetanic stimulation but it was if dipyridamole was present during the rest period following it, suggesting that adenosine's presence after tetanic stimulation is of importance. This conclusion was strengthened by experiments showing that the presence of cyclopentyltheophylline, an antagonist at inhibitory adenosine receptors, increased ACh output evoked by test stimulation immediately following tetanic activity, as if endogenous adenosine was available at that time to activate the adenosine receptors that inhibit transmitter release. ACh release from conditioned ganglia was $44 \%$ greater than that from the controls. However, the rebound ACh was not mobilized in the presence of 2-(4-phenylpiperidino)cyclohexanol (vesamicol), a vesicular ACh transporter inhibitor. These results suggest that endogenous adenosine released after tetanic stimulation activates ACh synthesis, which results in an in-

\footnotetext{
Received Nov. 29, 1993; revised Feb. 3, 1994; accepted Feb. 16, 1994.

We thank Ms. Anna McNicoll for her excellent technical assistance. A.T. received a studentship from the Faculty of Medicine of McGill University. This work was supported by a grant from the Medical Research Council of Canada.

Correspondence should be addressed to Anurag Tandon, Department of Pharmacology and Therapeutics, McGill University, 3665 Drummond Street, Montreal, Quebec, Canada, H3G 1 Y6.

Copyright (C) 1994 Society for Neuroscience $0270-6474 / 94 / 144927-10 \$ 05.00 / 0$
}

crease of ganglionic ACh that is available for subsequent mobilization and release.

[Key words: adenosine, ACh, synaptic potentiation, nucleoside transport, dipyridamole, superior cervical ganglion]

In a recent arlicle, we reported that adenosine can, under particular experimental conditions, increase the acetylcholine $(\mathrm{ACh})$ content of superior cervical ganglia (Tandon and Collier, 1993). This effect was manifest when adenosine was perfused through a ganglion at rest; it appeared not to result from an action of adenosine on the classical extracellular adenosine receptors in that it was not blocked by adenosine receptor antagonists, but it was prevented by agents like dipyridamole that block adenosine uptake. These properties clearly distinguish the effect of adcnosine to increase $\mathrm{ACh}$ stores from its well-studied effect to decrease transmitter release (see review by White, 1988); the latter effect is only manifest during stimulation, and it is blocked by receptor antagonists.

We showed in that initial report that the extra $\mathrm{ACh}$ synthesized in adenosine's presence was releasable after adenosine's removal, but, otherwise, its potential physiologic significance was not explored. The present work attempted to do so by testing if the adenosine phenomenon is related to a well-reported example of presynaptic adaption that is reflected as an increase in the ACh content of a sympathetic ganglion following a conditioning paradigm of high-frequency long-duration stimulation of its preganglionic input.

This poststimulation increase in ACh stores was first reported by Rosenblueth et al. (1939) and has been described subsequently in greater detail by Freisen and Khatter (1971), Birks and Fitch (1974), Bourdois et al. (1974), O'Regan and Collier (1981), and Collier et al. (1983). It results from an accelerated rate of $\mathrm{ACh}$ synthesis, possibly due to increased choline uptake (O'Regan and Collier, 1981; Collier et al., 1983), during a period of rest that follows the conditioning stimulation, and can increase tissue $\mathrm{ACh}$ by up to $70 \%$, depending upon the frequency and duration of the conditioning stimuli. The extra transmitter, which we will refer to as "rebound $\mathrm{ACh}$," is incorporated into a releasable pool (Bourdois et al., 1974; Birks, 1977; Collier et al., 1983), but there is some uncertainty about the particular intraterminal store that is augmented by the extra $\mathrm{ACh}$ synthesized. Although it is not clear that rebound $\mathrm{ACh}$ is formed under physiological conditions, other patterns of neuronal activity, which may occur in vivo, promote its formation; Birks (1978) reported that short repetitive bursts of high-frequency pulses could increase ACh content even though the same mean frequency, when applied in evenly spaced pulses, did not. In addition, experimental hypoxia produced a phenomenon similar 
to rebound ACh (Birks, 1978); this effect resulted from an increased discharge rate of preganglionic neurons because it was not evident if the cervical sympathetic trunk was first transected.

The mechanism by which the synthesis of rebound $\mathrm{ACh}$ is initiated remains to be elucidated; transmitter release during the tetanic conditioning is necessary for its induction (Collier et al., 1983), but the phenomenon appears not to require $\mathrm{ACh}$ action on muscarinic (Bourdois et al., 1974) or nicotinic (Collier et al., 1983) receptors. These observations suggest the possibility that some releasable factor other than $\mathrm{ACh}$ might be involved in initiating the synthesis of rebound $\mathrm{ACh}$. As mentioned above, adenosine can increase ganglionic ACh content, and thus suggested itself as a candidate for this putative factor that mediates the formation of the rebound $\mathrm{ACh}$, and the aim of the present study was to test this idea. To do so, we tested if the drugs that prevented the adenosine-induced increase in transmitter content could also affect the accumulation of rebound $\mathrm{ACh}$. If the two phenomena are related, they should have a similar pharmacological sensitivity to nucleoside transport inhibitors. A second related objective of this work was to examine the relationship between rebound $\mathrm{ACh}$ and the releasable $\mathrm{ACh}$ compartments in order to clarify the uncertainty mentioned above.

Some of this work has been presented in abstract form (Tandon and Collier, 1991).

\section{Materials and Methods}

Materials used. $\gamma^{-32} \mathrm{P}-\mathrm{ATP}(10 \mathrm{Ci} / \mathrm{mmol})$ was purchased from New England Nuclear (Boston, MA); butyronitrile was obtained from Aldrich Chemical Co. (Milwaukee, WI); OptiPhase HiSafe II was from LKB acetylcholine chloride was from Hoffmann-LaRoche (Basel, Switzerland); Meclonazepam and RO 11-3624 were generous gifts from Hoffmann-LaRoche (Mississauga, Canada); EGTA was obtained from Eastman Kodak (Rochester, NY); cyclohexyladenosine and cyclopentyltheophylline were from Research Biochemicals Inc. (Natick, MA); Amberlite CG-400 (chloride form), choline chloride, dipyridamole, nitrobenzylthioinosine, tetraphenylboron (sodium salt), $\alpha$-chloralose, acetylcholinesterase (EC 3.1.1.7, ACh hydrolase, type V-S), choline kinase (EC 2.7.1.32, ATP:choline phosphotransferase), and physostigmine sulfate were all purchased from Sigma Chemical Co. (St. Louis, MO). Vesamicol was a gift of Dr. S. M. Parsons (University of California at Santa Barbara) or was synthesized by Dr. T. H. Chan (McGill University) by reacting 4-phenylpiperidine (a gift of Dr. M. Peel, Glaxo) with cyclohexene oxide. All other chemicals and reagents were obtained from Fisher Scientific (Montreal, Quebec, Canada).

Experimental procedures. Anesthesia was induced in cats of either sex $(1.5-4.0 \mathrm{~kg})$ with a $2: 1$ mixture of $\mathrm{N}_{2} \mathrm{O} / \mathrm{O}_{2}$ with $2 \%$ halothane and maintained with an intravenous injection of $\alpha$-chloralose $(80 \mathrm{mg} / \mathrm{kg})$. Superior cervical ganglia were prepared surgically for perfusion according to the method of Kibjakow (1933) as described by Collier and Kwok (1982). All animal use procedures were in strict accordance with the guidelines of the Medical Research Council of Canada and the Canadian Council on Animal Care and were approved by the local Animal Care Committee. One or both ganglia were perfused $(0.2-0.4 \mathrm{ml} / \mathrm{min})$ with a Krebs solution of the following composition (mM): $\mathrm{NaCl}, 120 ; \mathrm{KCl}$, 4.6; $\mathrm{CaCl}_{2}, 2.4 ; \mathrm{KH}_{2} \mathrm{PO}_{4}, 1.2 ; \mathrm{MgSO}_{4}, 1.2 ; \mathrm{NaHCO}_{3}, 25 ;$ and dextrose, 10. Choline chloride $(10 \mu \mathrm{M})$ was always added before perfusion. The medium was filtered and subsequently equilibrated with $5 \% \mathrm{CO}_{2}$ in $\mathrm{O}_{2}$ to maintain a pH of 7.4 at $37^{\circ} \mathrm{C}$. In experiments that measured $\mathrm{ACh}$ release, the perfusion medium also contained physostigmine sulfate (15 $\mu \mathrm{M}$ ); other drugs were used as described in the appropriate text.

All drugs were added to the Krebs solution just before perfusion. After the perfusion, ganglia were excised and placed in $1 \mathrm{ml}$ of $10 \%$ trichloroacetic acid (TCA) for $1 \mathrm{hr}$ on ice. In an effort to shorten the period of rest following tetanic stimulation in some experiments, the ganglia were dissected from the distal end first so that preganglionic stimulation could be maintained until placement into ice-cold TCA. The TCA was removed by extraction with ether and the aqueous layer was assayed for ACh content.

Ganglia were stimulated via the preganglionic sympathetic trunk with square wave pulses $(8-10 \mathrm{~V}, 0.5 \mathrm{msec}, 5$ or $15 \mathrm{~Hz})$ using a platinum electrode. During periods of prolonged stimulation, the electrode was moved a few millimeters proximally along the nerve every $10 \mathrm{~min}$. When measuring $A C h$ release, the perfusate was collected in 2 or $5 \mathrm{~min}$ periods into prechilled tubes and stored on ice for not more than $1 \mathrm{hr}$. Samples were stored overnight at $-20^{\circ} \mathrm{C}$ for assay the following day.

Measurement of $A C h$. ACh was obtained from the aqueous tissue extracts and the perfusate samples by the method of Fonnum (1969), as described by Welner and Collier (1984). Briefly, the samples were extracted by $400 \mu \mathrm{l}$ of tetraphenylboron in butyronitrile (TPB/butyronitrile; $10 \mathrm{mg} / \mathrm{ml}$ ). The choline esters were removed from the organic phase by $150 \mu \mathrm{l}$ of $\mathrm{AgNO}_{3}(20 \mathrm{mg} / \mathrm{ml})$; excess silver was precipitated with $10 \mu \mathrm{l}$ of $\mathrm{MgCl}_{2}(1 \mathrm{M})$. Samples were lyophilized to dryness.

The ACh content of the samples was determined according to the radioenzymatic method of Goldberg and McCaman (1973). Choline was phosphorylated by choline kinase and ATP. AC'h was hydrolyzed to choline with acetylcholinesterase and phosphorylated with $\gamma-{ }^{32} \mathrm{P}$ ATP. The phosphorylated choline was separated from the labeled ATP by anion-exchange chromatography and the radioactivity measured by liquid scintillation spectrometry. ${ }^{32} \mathrm{P}$ was measured in $10 \mathrm{ml}$ of OptiPhase HiSafe II with an counting efficiency of $99 \%$.

Statistical analysis. Statistical comparisons were done using two-tailed Student's $t$ test for paired samples. This analysis was appropriate for all comparisons between the two ganglia of each animal: one was used as the test preparation and its contralateral served as control. The values are presented as percentage or amount of change; each such value was calculated for each pair of ganglia. To evaluate differences between unpaired conditions, ANOVA and Newman-Keuls for the post hoc comparison were used.

\section{Results}

Effect of nucleoside transport inhibitors on the accumulation of rebound $\mathrm{ACh}$

Nucleoside transporters are classified into two groups on the basis of their sensitivity to inhibition by nitrobenzylthioinosine (NBTI), that is, NBTI-sensitive or NBTI-resistant nucleoside transporters; both types are blocked by dipyridamole. The initial experiments tested whether the synthesis of rebound $\mathrm{ACh}$ is altered by the presence of nucleoside transport inhibitors. In these tests, the ACh content of the contralateral ganglion, neither stimulated nor exposed to the nucleoside transport inhibitors, allowed us to estimate the initial $\mathrm{ACh}$ content of the test ganglion since the amount of transmitter contained in both superior cervical ganglia is normally the same (Feldberg, 1943; Birks and MacIntosh, 1961). The test ganglia were subjected to preganglionic stimulation at $15 \mathrm{~Hz}$ for $45 \mathrm{~min}$ and then allowed to rest for $15 \mathrm{~min}$. Conditioning of this nature has been previously shown to increase ganglionic ACh stores (see introductory remarks) and the present experiments yielded similar results; the ACh content of the conditioned ganglia was increased by 588 $\pm 113 \mathrm{pmol}(45 \pm 11 \%, n=7 ; p<0.01)$ when compared to the contralateral ganglia, which contained $1397 \pm 136$ pmol (Fig. 1). When ganglia were conditioned and then rested with $10 \mu \mathrm{M}$ dipyridamole present throughout the experiment, the increase in ACh content was $163 \pm 66 \mathrm{pmol}(11 \pm 5 \%, n=5$; $0.1>p>0.05$ ), significantly less than in dipyridamole's absence ( $p<0.05$, ANOVA/Newman-Keuls). In contrast, when 100 $\mu \mathrm{M}$ NBTI was present, the amount of extra ACh contained was increased to $1289 \pm 212 \operatorname{pmol}(88 \pm 10 \%, n=5 ; p<0.01)$, more than double the increase produced by conditioning alone $(p<0.05$, ANOVA/Newman-Keuls).

The two classes of transporters mentioned above exhibit stereoselectivity with respect to the two benzodiazepine stereoisomers RO 1 1-3624 and meclonazepam (formerly called RO 11 3128 ). Both transporters are equally sensitive to RO 11-3624, but the NBTI-resistant carrier is 50 -fold less sensitive to meclonazepam (Lee and Jarvis, 1988a). Thus, we tested these agents 


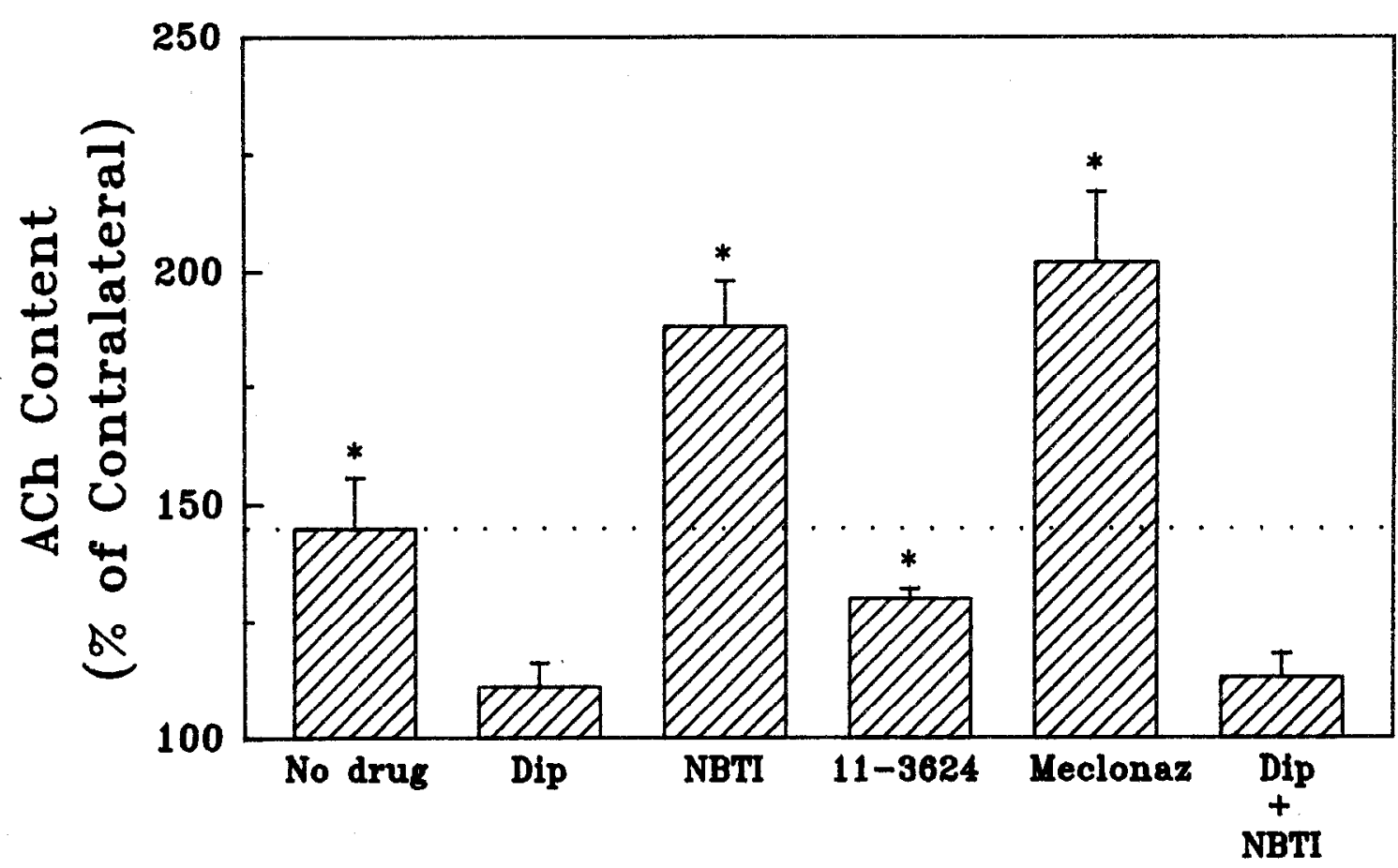

Figure 1. Effect of nucleoside transport inhibitors on the accumulation of rebound ACh. Ganglia were perfused with a Krebs solution (No drug) or one containing one or more of the following: dipyridamole (Dip; $10 \mu \mathrm{M})$, nitrobenzylthioinosine $(N B T I ; 100 \mu \mathrm{M}), \mathrm{RO} 11-3624$ (11-3624; 100 $\mu \mathrm{M}$ ), or meclonazepam (Meclonaz.: $100 \mu \mathrm{M}$ ). The ganglia were stimulated at $15 \mathrm{~Hz}$ for $45 \mathrm{~min}$ and then allowed to rest for $15 \mathrm{~min}$. Bars represent ACh content (means \pm SEM of three to seven experiments) of stimulated ganglia as a percentage of the contralateral ganglion's value (mean contralateral ACh content was $1450 \pm 57 \mathrm{pmol}$ ). ${ }^{*}, p<0.05$, increased ACh content compared to contralateral control ganglion.

to determine if their effects were similar to those of dipyridamole and NBTI reported above. When ganglia were conditioned and rested with $100 \mu \mathrm{M}$ RO 11-3624 present throughout, the synthesis of rebound $\mathrm{ACh}$ was $418 \pm 39 \mathrm{pmol}(30 \pm 2 \%$ of the initial content), approximately $30 \%$ less than that produced by conditioning in the absence of drug. This change, however, represented a significant increase in $\mathrm{ACh}$ content compared to the contralateral ganglia $(p<0.05)$. In contrast to RO 11-3624, exposure of ganglia to $100 \mu \mathrm{M}$ meclonazepam throughout the experiment increased the accumulation of extra ACh to 1445 \pm 301 pmol $(102 \pm 15 \%, p<0.01)$, significantly greater than that in the presence of its stereoisomer $(p<0.01$, ANOVA/ Newman-Keuls) (Fig. 1).

To test whether dipyridamole could prevent the extra $\mathrm{ACh}$ induced by NBTI, ganglia were stimulated and rested in the presence of both dipyridamole and NBTI. In three such experiments, the ACh content of conditioned ganglia was increased by only $219 \pm 96 \mathrm{pmol}(14 \pm 6 \%$ compared to the contralateral ACh content of $1493 \pm 113 \mathrm{pmol})$. This change was not statistically significant $(0.2>p>0.1)$ and was not different from that observed in ganglia conditioned and rested in the presence of dipyridamole alone; it was clearly less than the change in the presence of NBTI alone (Fig. 1).

\section{Effect of dipyridamole on $A C h$ release and $A C h$ stores without conditioning}

Dipyridamole reduced the accumulation of rebound $\mathrm{ACh}$ in the tests above, just as it reduced the adenosine-induced increase in ACh synthesis (Tandon and Collier, 1993). Before concluding that this might indicate a role for endogenous adenosine in the formation of rebound $\mathrm{ACh}$, it was necessary to assess the effects of dipyridamole on $\mathrm{ACh}$ turnover during stimulation; trans- mitter release during stimulation is necessary for the increased synthesis following conditioning (Collier et al., 1983). It has been suggested that dipyridamole interacts with the glucose transporter, and although in earlier tests dipyridamole did not affect basal ACh synthesis in resting ganglia (Tandon and Collier, 1993), it remained possible that dipyridamole might inhibit $\mathrm{ACh}$ release or reduce $\mathrm{ACh}$ synthesis during stimulation and, consequently, mask the appearance of rebound ACh.

To test the effect of dipyridamole on transmitter release, $\mathrm{ACh}$ output was measured from ganglia stimulated in the presence of dipyridamole. In these experiments, $\mathrm{ACh}$ release was measured from both ganglia of each cat before, during, and after the conditioning stimulation ( $45 \mathrm{~min}$ of $15 \mathrm{~Hz}$ stimulation preceding $15 \mathrm{~min}$ of rest); one ganglion was exposed to $10 \mu \mathrm{M}$ dipyridamole during this timc. Physostigmine $(15 \mu \mathrm{M})$ was present throughout the experiment to prevent the loss of secreted $\mathrm{ACh}$ due to cholinesterase activity. As illustrated in Figure $2 a$, basal ACh output before stimulation was similar between the test and control ganglia $(5.3 \pm 0.7$ vs $5.1 \pm 0.7 \mathrm{pmol} / \mathrm{min}$, respectively). Preganglionic stimulation clearly increased $\mathrm{ACh}$ release above the basal output from both ganglia. Dipyridamole did not inhibit evoked $\mathrm{ACh}$ release; indeed, it appeared to augment initial transmitter output somewhat, but this difference did not reach statistical significance. The total evoked ACh output from dipyridamole-treated ganglia (3266 $\pm 589 \mathrm{pmol})$ was not different from that released by the control ganglia $(3006 \pm 220 \mathrm{pmol})$. Moreover, ACh efflux from both sets of ganglia returned to basal values following the stimulation period. The transmitter retained in these ganglia following the conditioning and rest was also measured (Fig. 2b). These ACh levels were clearly greater than the normal ACh content (compare to mean of 29 control ganglia from experiments in the previous section: $1450 \pm 57$ 


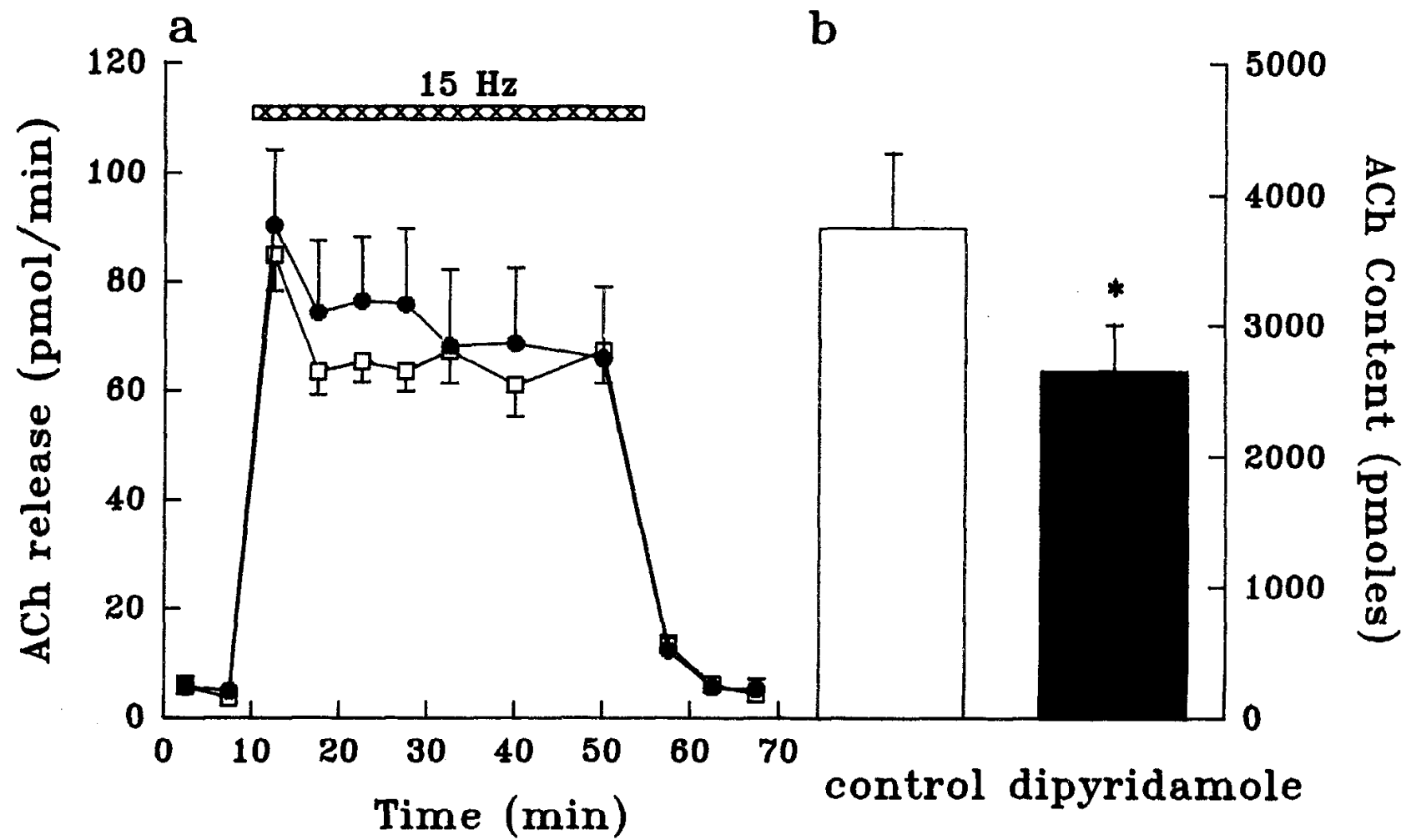

Figure 2. Effect of dipyridamole on ACh release. Both ganglia of each animal were perfused with a Krebs solution containing $15 \mu \mathrm{M}$ physostigmine for $70 \mathrm{~min}$; the test ganglion was also exposed to $10 \mu \mathrm{M}$ dipyridamole. $a$, ACh release in the absence (D) or presence $(\mathbf{O})$ of dipyridamole from ganglia rested for $10 \mathrm{~min}$, stimulated for $45 \mathrm{~min}$ at $15 \mathrm{~Hz}$ (indicated by horizontal bar), and then allowed to rest for $15 \mathrm{~min}$. $b$, ACh content of ganglia following the stimulation and rest periods. Results shown are the mean \pm SEM of 5 experiments. ${ }^{*}, p<0.05$.

pmol), as was expected due to the presence of physostigmine in the perfusion buffer, which promotes the accumulation of "surplus ACh," resulting in a doubling of the transmitter content (Birks and MacIntosh, 1961). However, as in the experiments

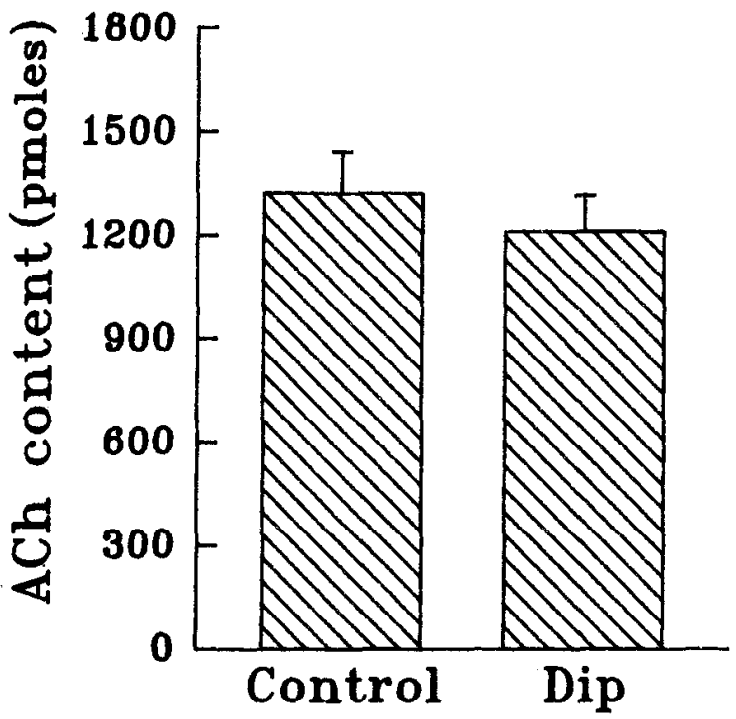

Figure 3. Effect of dipyridamole on ACh content following stimulation. Pairs of ganglia were perfused with a Krebs solution and stimulated for $45 \mathrm{~min}$ at $15 \mathrm{~Hz}$, one ganglion of each pair was also exposed to 10 $\mu \mathrm{M}$ dipyridamole. Bars represent mean \pm SEM of ACh content of five experiments. without physostigmine, the tissues that had been perfused with dipyridamole contained some $30 \%$ less ACh than did those not exposed to that drug. Indeed, the amount of ACh (1097 \pm 320 pmol) by which the untreated and treated ganglia differed was greater in these experiments than it was in the ones without physostigmine $(588 \mathrm{pmol})$, as if the presence of physostigmine might increase the accumulation of rebound ACh.

In other experiments, we tested the effect of dipyridamole on ACh synthesis during stimulation in the absence of physostigmine. Normally, the production of transmitter is augmented during neuronal activity to match $\mathrm{ACh}$ output such that tissue ACh stores are maintained relatively constant. We verified this in five experiments in which one ganglion of each cat was stimulated at $15 \mathrm{~Hz}$ for $45 \mathrm{~min}$ before its removal (stimulation of the preganglionic nerve was maintained during excision of these ganglia so that the amount of time between the end of stimulation and placement in ice-cold TCA was minimal). The ACh content of the stimulated ganglia was $1692 \pm 129$ pmol, comparable to the $1707 \pm 182 \mathrm{pmol}$ of the contralateral ganglia, indicating that $\mathrm{ACh}$ synthesis indeed maintained $\mathrm{ACh}$ content during stimulation. Since release was not affected by dipyridamole, as shown above, any decreased ACh synthesis caused by the drug would be manifest as a decrease in ACh content at the end of stimulation. Both ganglia of each cat were perfused with Krebs buffer while one ganglion was also exposed to $10 \mu \mathrm{M}$ dipyridamole. The ganglia were stimulated for $45 \mathrm{~min}$ before being excised and assayed for tissue $\mathrm{ACh}$. In five such experiments, the ACh content of the ganglia stimulated in the presence of dipyridamole was $93 \pm 4 \%$ of the contralateral content, a 


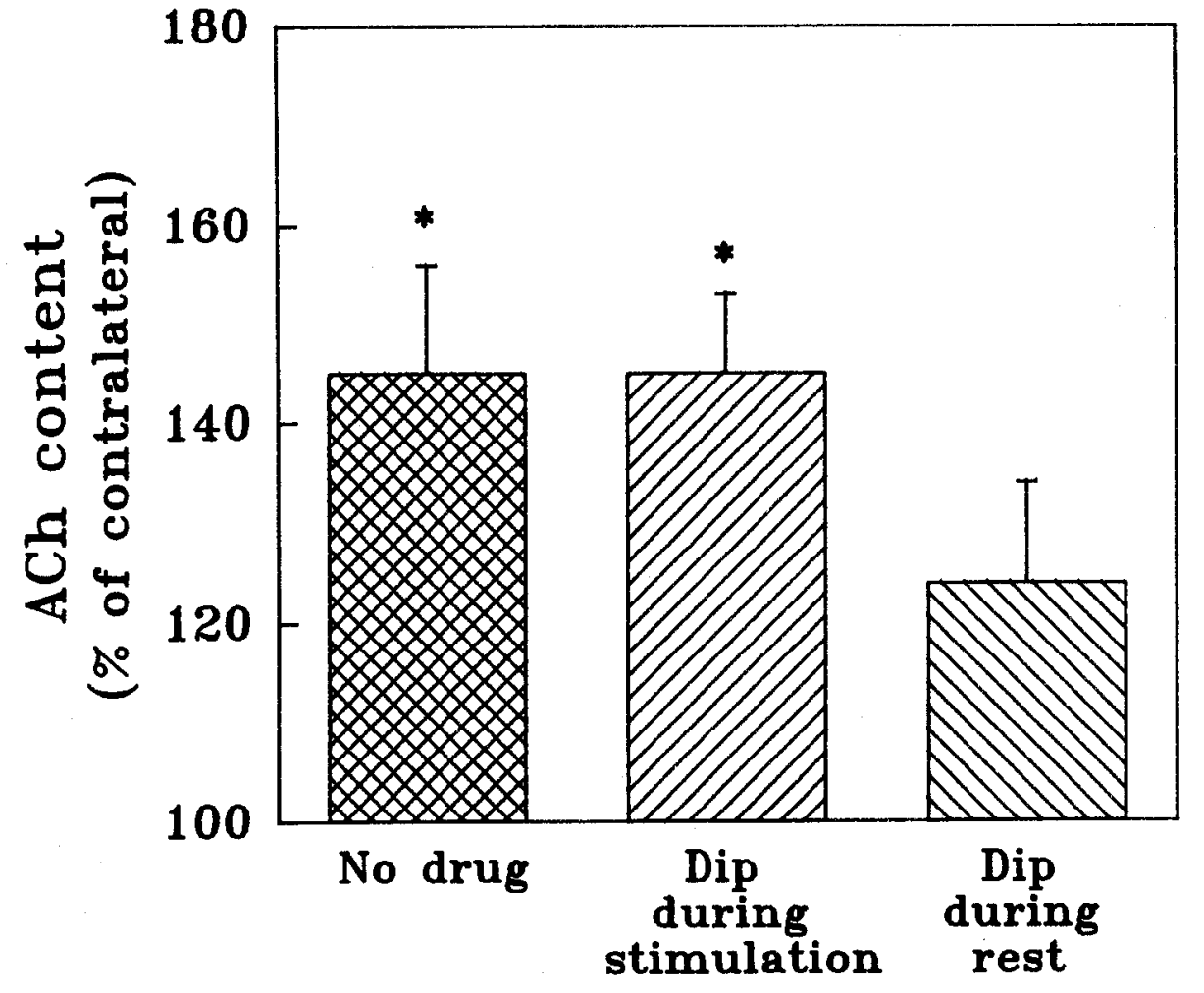

Figure 4. Effect of dipyridamole during stimulation or during rest. Ganglia were stimulated for $45 \mathrm{~min}$ at $15 \mathrm{~Hz}$ and then allowed to rest for $15 \mathrm{~min}$. Dipyridamole was present either during the stimulation $(n=4)$ or during the rest period $(n=6)$. For comparison, the control (no drug) from Figure 1 is also shown. The bars represent $\mathrm{ACh}$ content of the test ganglion expressed as a percentage \pm SEM of that in the contralateral ganglion (mean contralateral ACh content: $1349 \pm 65$ pmol). ${ }^{*}$, $p<0.05$. mean reduction of $106 \pm 55 \mathrm{pmol}$. The difference did not reach statistical significance $(0.2>p>0.1$; Fig. 3$)$.

Thus, neither evoked $\mathrm{ACh}$ release nor $\mathrm{ACh}$ content was altered significantly during dipyridamole exposure, indicating that net ACh synthesis during prolonged stimulation is not affected by the drug. Dipyridamole appears to inhibit specifically the posttetanic potentiation of $\mathrm{ACh}$ stores without compromising the ability of nerve terminals to maintain their normal stores.

\section{Effectiveness of dipyridamole to inhibit rebound $\mathrm{ACh}$ accumulation during stimulation or rest}

To test whether the action of dipyridamole to inhibit the synthesis of rebound $\mathrm{ACh}$ requires its presence during the tetanic stimulation or during the period of rest following the stimulation, one ganglion of each cat was subjected to the conditioning as before, but instead of continuous exposure to dipyridamole throughout the experiment, the drug was present only for the 45 min stimulation period or for the subsequent 15 min rest period. Exposure to dipyridamole only during stimulation had no effect on the accumulation of rebound $\mathrm{ACh}$; transmitter stores were increased by $613 \pm 133 \mathrm{pmol}(45 \pm 8 \%, n=4 ; p<0.01)$ compared to the contralateral ACh content (Fig. 4). However, in the presence of dipyridamole only during the rest period, only $344 \perp 133 \mathrm{pmol}(24 \pm 10 \%, n=6)$ of extra $\Lambda \mathrm{Ch}$ was formed. This increase failed to be statistically significant in comparison to the ACh content of contralateral control ganglion $(0.05<p$ $<0.1)$. Thus, the dipyridamole-sensitive signal involved in stimulating the synthesis of rebound $\mathrm{ACh}$ appears to be manifest mainly following the tetanic stimulation, not during it.

Effect of an adenosine receptor antagonist on $A C h$ release during and following tetanic stimulation

The inhibitory effects of adenosine on neurotransmission are well characterized and the present experiments confirmed this

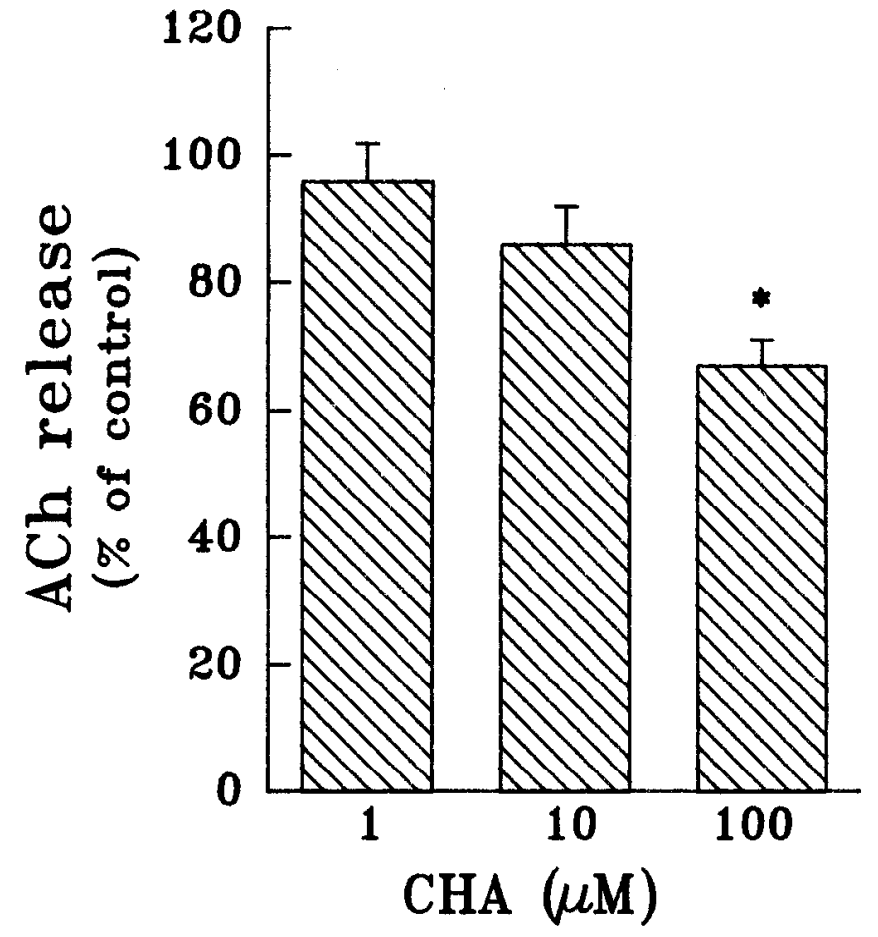

Figure 5. Concentration-dependent effect of cyclohexyladenosine $(\mathrm{CHA})$ on $\mathrm{ACh}$ release. Ganglia were perfused with $15 \mu \mathrm{M}$ physostigmine and increasing concentrations of CHA during $5 \mathrm{~Hz}$ stimulation $(r=3)$. ACh release is shown as a percentage \pm SEM of the control ACh release evoked by $5 \mathrm{~Hz}$ stimulation. Mean ACh output evoked by $5 \mathrm{~Hz}$ stimulation in the presence of $0,1,10$, and $100 \mu \mathrm{M} \mathrm{CH} \Lambda$ was $58 \pm 5,55$ $\pm 6,48 \pm 3$, and $39 \pm 4 \mathrm{pmol} / \mathrm{min}$, respectively. ${ }^{*}, p<0.05$. 
Figure 6. Effect of cyclopentyltheophylline (CPT) on ACh release. Pairs of ganglia were perfused with Krebs medium containing $15 \mu \mathrm{M}$ physostigmine; one ganglion of each pair was also exposed to $100 \mu \mathrm{M}$ CPT. Ganglia were stimulated at $15 \mathrm{~Hz}$ for $45 \mathrm{~min}$ (hatched bar), followed by 2 min of rest to washout released $\mathrm{ACh}$, and then stimulated at $5 \mathrm{~Hz}$ (crosshatched bar) for another $25 \mathrm{~min}$. ACh release is shown from control $(\square)$ and CPT-exposed ( $\square$ ) ganglia (means \pm SEM of six experiments). *, $p<0.02$.

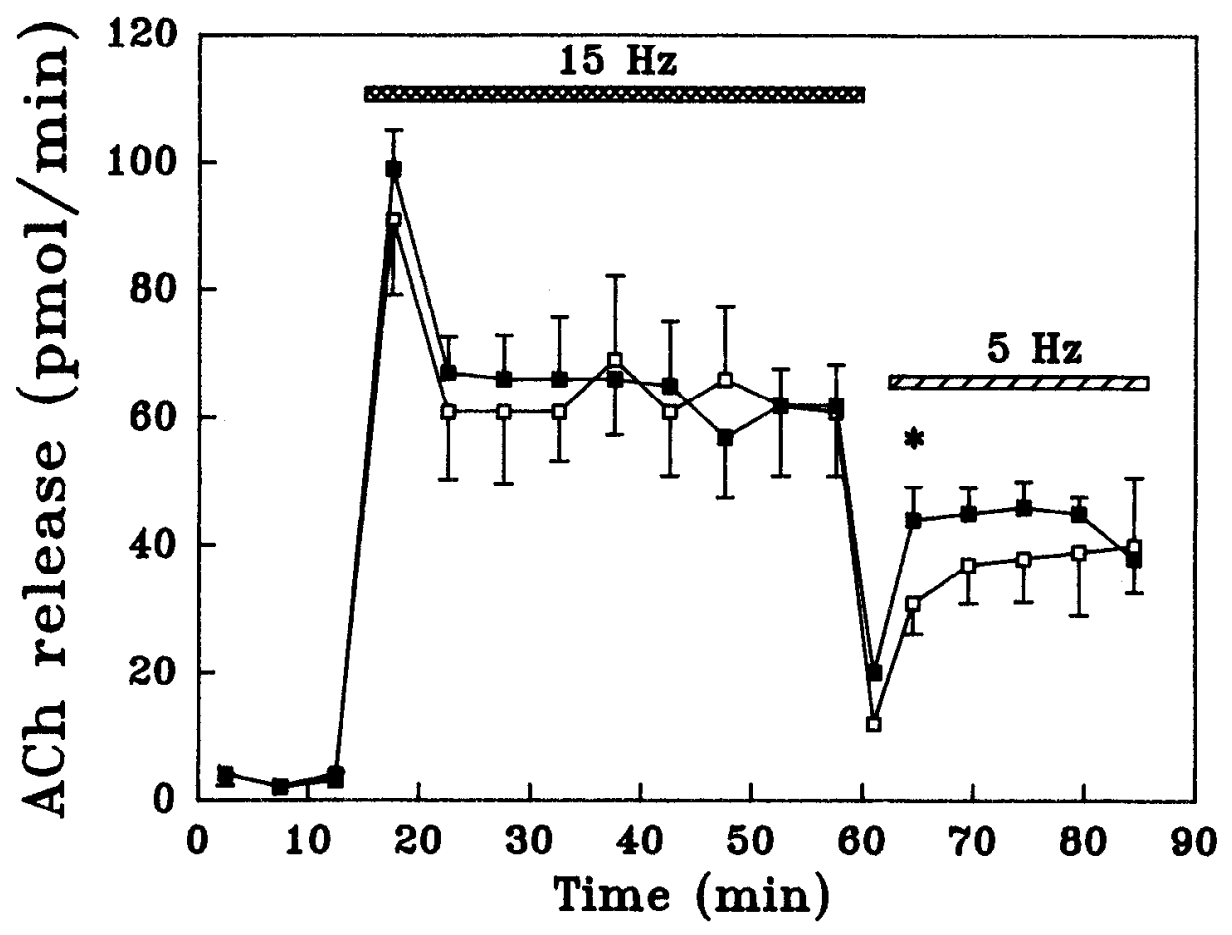

using cyclohexyladenosine (CHA) as the agonist. CHA decreased $\mathrm{ACh}$ release evoked by $5 \mathrm{~Hz}$ stimulation in a concentration-dependent manner (Fig. 5).

These data, indicating that adenosine receptor activation during stimulation significantly lessens ACh output measured at 5 $\mathrm{Hz}$, suggested a way to test whether adenosine is released following tetanic stimulation, as was implied by the result of Figure 4. The prediction was that if adenosine is released immediately following the tetanic stimulation, its presence might have an inhibitory action on evoked ACh release during this period due to an interaction with inhibitory adenosine receptors. Cyclopentyltheophylline (CPT) was used as the adenosine antagonist. Both ganglia of six cats were perfused with Krebs buffer containing physostigmine (15 $\mu \mathrm{M}$ ); one ganglion of each pair was perfused with medium that also contained $100 \mu \mathrm{M}$ CPT. Both ganglia were stimulated at $15 \mathrm{~Hz}$ for $45 \mathrm{~min}$, allowed to rest for 2 min to allow for the washout of ACh released by the preceding stimuli, and then they were subjected to a test stimulation of 5 $\mathrm{Hz}$. The effluent was collected in successive $5 \mathrm{~min}$ pcriods following the onset of each stimulation period. The pattern of $\mathrm{ACh}$ output from these experiments is shown in Figure 6 . The basal release from ganglia perfused with CPT was similar to that from control ganglia, indicating that the drug alone did not promote ACh release. The onset of $15 \mathrm{~Hz}$ stimulation was accompanied by rapid rise in $\mathrm{ACh}$ release in the first collection, which subsequently stabilized at a lower output rate from both sets of ganglia; no difference in the pattern or the amount of $\mathrm{ACh}$ released was evident whether CPT was present or not. Initiation of the subsequent $5 \mathrm{~Hz}$ test stimulation increased $\mathrm{ACh}$ release from both sets of ganglia, expectedly lower than that observed in the first stimulation period because of the lower frequency used, and the ACh released from the CPT-treated ganglia was $40 \%$ greater $(p<0.02$ ) during the first collection than that from the contralateral controls. ACh output in the subsequent collections also tended to be greater but failed to be statistically significant. The rate of release was stable from the drug-treated ganglia, but from the control ganglia, it increased progressively during the entire stimulation period. These results are suggestive of an inhibitory action of endogenous adenosine present just following the end of the $15 \mathrm{~Hz}$ stimulation, and support the argument that adenosine is present in effective concentration within the synaptic cleft following prolonged high-frequency stimulation.

\section{Potentiation of $A C h$ release following conditioning}

Previous studies suggested that transmitter release is potentiated following the formation of rebound $\mathrm{ACh}$, but the time course of potentiation was somewhat equivocal; in one study, $\mathrm{ACh}$ release following the conditioning and rest protocol was potentiated, but only after 2000 impulses had been delivered (Bourdois et al., 1974). On the other hand, Birks (1977) found that ACh release was increased immediately upon stimulation in proportion to the amount of extra ACh available. To examine this issue, both ganglia of six cats were prepared for perfusion. Onc ganglion was perfused with Krebs medium for $45 \mathrm{~min}$, during which time it was conditioned with $15 \mathrm{~Hz}$ preganglionic stimulation. The medium was then changed to one with physostigmine $(15 \mu \mathrm{M})$ and the ganglion was rested for $15 \mathrm{~min}$, before being stimulated with a $5 \mathrm{~Hz}$ test stimulation for another $45 \mathrm{~min}$. The contralateral ganglion did not receive the conditioning stimulation, but was perfused with Krebs medium containing physostigmine and subjected only to the test train of 5 $\mathrm{Hz}$ stimulation for $45 \mathrm{~min}$. ACh release was measured from both ganglia during the $5 \mathrm{~Hz}$ stimulation. As shown in Figure 7 , basal ACh release was similar whether or not the ganglia had been subjected to the conditioning stimulation. However, $\mathrm{ACh}$ output evoked by the $5 \mathrm{~Hz}$ test stimulation (i.e., total $\mathrm{ACh}$ output minus basal $\mathrm{ACh}$ output) was greater from the conditioned ganglia compared to the contralateral controls and remained so for the duration of the simulation period. Overall, the conditioned ganglia relcascd $44 \pm 15 \%(p<0.05)$ more ACh than did their contralateral controls (Fig. 7 , inset). The 


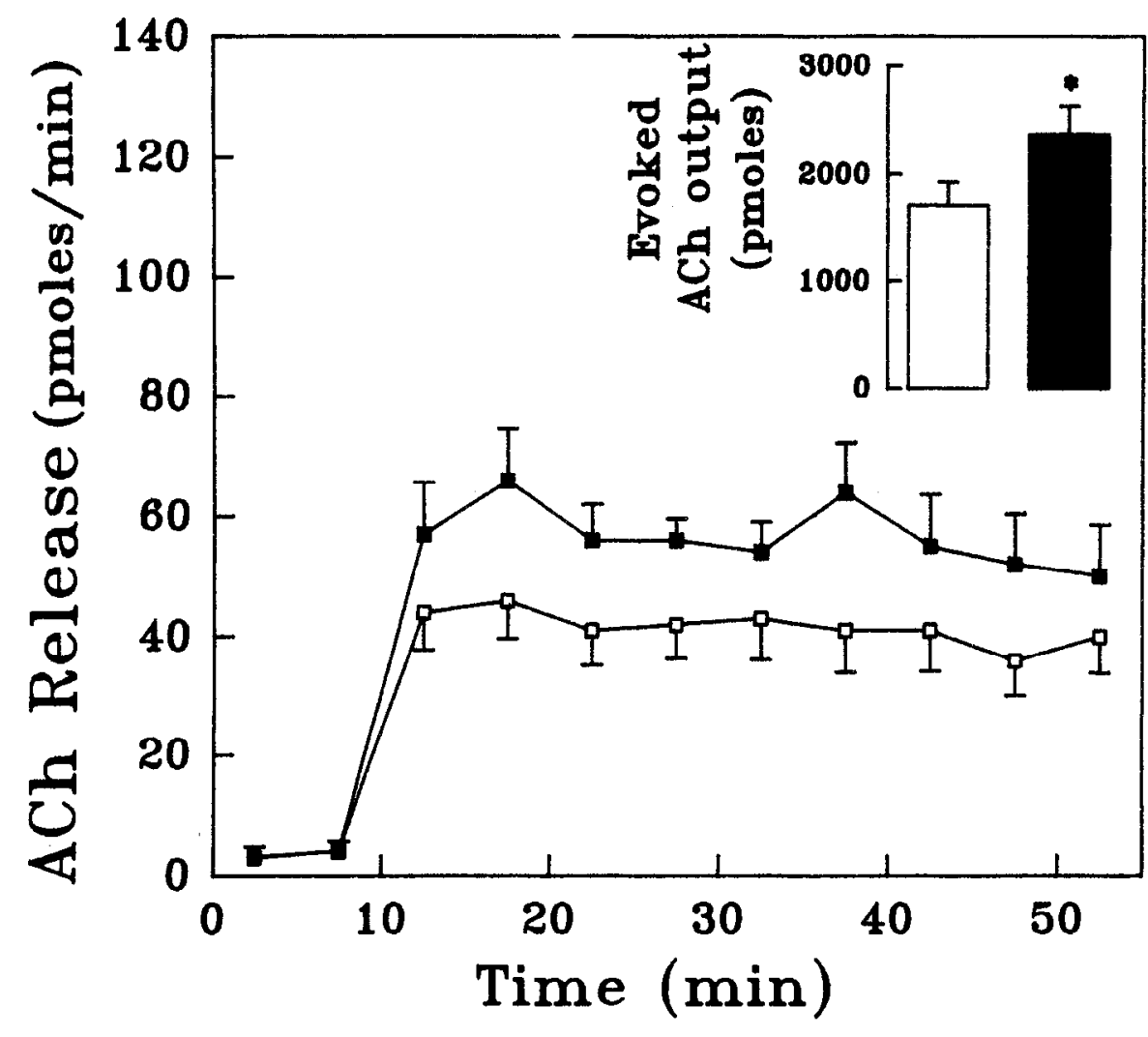

Figure 7. Release of ACh from conditioned and control ganglia. The test ganglia had been conditioned for $45 \mathrm{~min}$ with $15 \mathrm{~Hz}$ stimulation, and then allowed a $15 \mathrm{~min}$ rest during which time the medium was changed to one with physostigmine $(15 \mu \mathrm{M})$. Following the rest, the ganglia were stimulated at 5 $\mathrm{Hz}$ for $45 \mathrm{~min}$ and $\mathrm{ACh}$ release from these tissues is compared to that from the contralateral ganglia that had not been conditioned. ACh release during the $5 \mathrm{~Hz}$ test stimulation from the control $(\square)$ and conditioned $(\square)$ ganglia is shown as means \pm SEM of six experiments. Inset, Total evoked release from control (open bar) and conditioned (solid bar). Evoked release was calculated as the total $\mathrm{ACh}$ release minus the mean basal output estimated from measures before stimulation. amount of $\mathrm{ACh}$ remaining in these ganglia was measured at the end of the experiment; the $\mathrm{ACh}$ content of the conditioned ganglia was similar to that of their unconditioned counterparts (2960 \pm 331 and $2710 \pm 366$ pmol, respectively), indicating that the conditioned ganglia do not retain their extra $\mathrm{ACh}$ during stimulation. Thus, initial ACh output is increased in proportion to the increase in transmitter content, although toward the end of the experiment this relationship does not hold, as the rate of ACh output remains high while ACh content returns to control levels.

\section{Relationship between rebound $A C h$ and the readily releasable compartment of $\mathrm{ACh}$}

Preganglionic nerve stimulation in the presence of vesamicol (formerly known as AH5183), a vesicular ACh transport blocker, releases only approximately $14 \%$ of the total ACh stores that is considered to represent the readily releasable pool of $\mathrm{ACh}$ (as defined by Birks and MacIntosh, 1961) by virtue of its similarity in both quantity and its temporal pattern of release (Collier et al., 1986). As shown above, rebound $\mathrm{ACh}$ is associated with a releasable pool following its synthesis, resulting in increased ACh output, but it is not known whether the size of the readily releasable pool or the mobilization of $\mathrm{ACh}$ is altered as a consequence of this extra $\mathrm{ACh}$.

To test this point, both ganglia of each cat were perfused with Krebs buffer for $1 \mathrm{hr}$. One ganglion of each pair was perfused at rest for this period, while the second ganglion was conditioned with $45 \mathrm{~min}$ of $15 \mathrm{~Hz}$ stimulation followed by a $15 \mathrm{~min}$ rest. The medium was then changed to one containing vesamicol (10 $\mu \mathrm{M})$ and physostigminc $(15 \mu \mathrm{M})$. Following another $10 \mathrm{~min}$, during which time the effluent was collected for measurement of basal ACh release, the sympathetic trunk was stimulated at a rate of $5 \mathrm{~Hz}$ and the samples collected every $2 \mathrm{~min}$ for the first $10 \mathrm{~min}$ and subsequently every $5 \mathrm{~min}$ for another $20 \mathrm{~min}$. The conditioning did not affect basal $\mathrm{ACh}$ release or the pattern of ACh release evoked by stimulation compared to the controls (Fig. 8). Moreover, the amount of $\mathrm{ACh}$ released as a result of stimulation was unchanged by the conditioning (Fig. 8 , inset). Thus, the size of the readily releasable pool is not modified by the rebound $\mathrm{ACh}$, and the increased $\mathrm{ACh}$ release (Fig. 7) presumably results from increased mobilization of transmitter.

\section{Discussion}

The role of endogenous adenosine in the accumulation of rebound $\mathrm{ACh}$

The present experiments were initiated in an attempt to test whether adenosine plays a role in an adaptive response of cholinergic nerve terminals that is caused by a period of conditioning stimulation. The rebound phenomenon is fairly well described in the literature (see introductory remarks); it is manifest as an increase in $\mathrm{ACh}$ stores as a result of increased synthesis following prolonged tetanic activity. An increase in $\mathrm{ACh}$ content is evident in the presence of adenosine also (Tandon and Collier, 1993), and thus, it appeared possible that this purine, if endogenously released, could mediate the synthesis of rebound $\mathrm{ACh}$.

We have shown previously that the adenosine effect to increase ACh stores was prevented by dipyridamole, an inhibitor of nucleoside transport. In the present work, dipyridamole clearly reduced the accumulation of rebound $\mathrm{ACh}$, supporting the notion that adenosine might be involved in activating rebound ACh synthesis. Dipyridamole's reported ability to inhibit glucose transport (Deuticke et al., 1964) is unlikely to have been a factor in this action because neither $\mathrm{ACh}$ synthesis nor $\mathrm{ACh}$ release was altered by dipyridamole during prolonged stimulation. As both synthesis and release are highly sensitive to glucose deprivation during neuronal activity and cannot be sus- 
Figure 8. Effect of vesamicol on the release of rebound ACh. Both ganglia had been perfused with Krebs medium for $1 \mathrm{hr}$. One ganglion was stimulated for $45 \mathrm{~min}$ at $15 \mathrm{~Hz}$ and then allowed a 15 min rest while the other ganglion was rested. The medium was changed to one containing vesamicol $(10 \mu \mathrm{M})$ and physostigmine $(15 \mu \mathrm{M})$. Following another $10 \mathrm{~min}$ of rest, the preganglionic trunk was stimulated at $5 \mathrm{~Hz}$ and the $\mathrm{ACh}$ output was measured from the control $(\mathrm{O})$ and conditioned $(\bullet)$ ganglia and is shown as means of six experiments. Error bars have been omitted for clarity, and the variation ( \pm SEM) is shown in the inset, which illustrates total evoked $\mathrm{ACh}$ release from control (open bar) and conditioned (solid bar) ganglia in the presence of vesamicol. Evoked release was calculated as the total $\mathrm{ACh}$ release minus the mean basal output estimated from measures before stimulation.

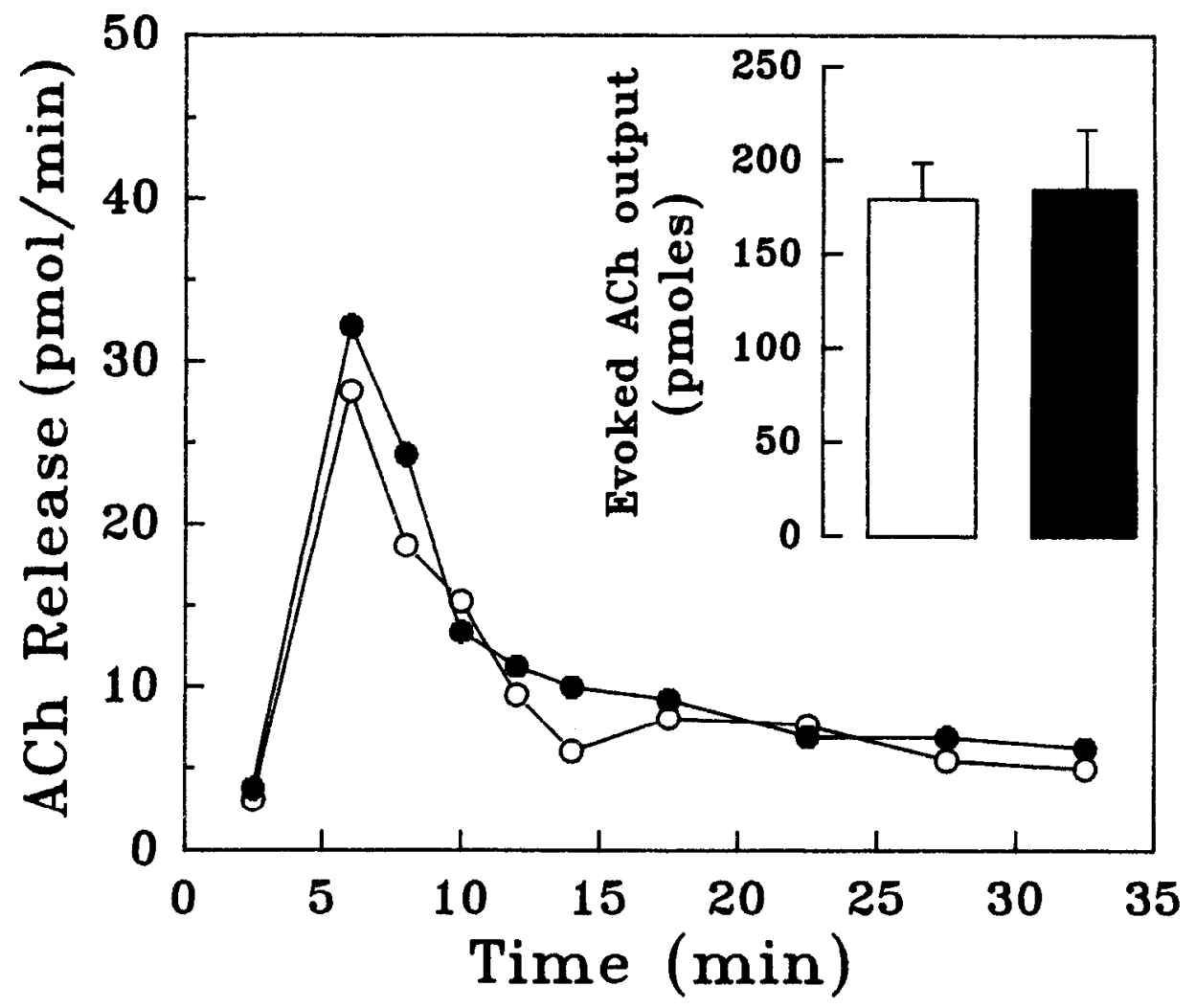

ing the test stimulation after high-frequency activity increased in the absence of CPT but did not in its presence (see Fig. 6), possibly indicating that the time course or amount of adenosine release was somewhat variable between individual preparations. A similar variability in evoked $\mathrm{ACh}$ discharge following a prolonged high-frequency stimulation was reported by Birks (1977).

Overall, these pharmacological tests support the possibility that adenosine acts as a signal to initiate the synthesis of rebound $\mathrm{ACh}$ after high-frequency stimulation. However, some of our results might not be entirely consistent with adenosine as the only mediator of this phenomenon. First, dipyridamole present following the stimulation was only partly effective, perhaps because its access to its target was delayed when the perfusion medium was changed following tetanic stimulation, but possibly indicating that adenosine was only partly responsible. Second, RO 11-3624, an agent pharmacologically similar to dipyridamole in its ability to block both the NBTI-sensitive and -resistant carriers with equivalent potency (Lee and Jarvis, 1988a), only partly inhibited the accumulation of rebound $\mathrm{ACh}$, although in previous tests, the same concentration as used here was as effective as dipyridamole to decrease the adenosine effect. This also could indicate a role for some mediator other than adenosine; however, it must be kept in mind that the efficacy of this compound to block completely movement of adenosine through the NBTI-resistant transporters has not been properly studied. Shank and Baldy (1990) have reported that at least two, possibly three, NBTI-resistant nucleoside transport systems can be distinguished in synaptosomes prepared from rat or guinea pig cerebral cortex, and the possibility that inhibition by $\mathrm{RO}$ 11-3624 is incomplete in one or more of these systems cannot be excluded.

An interesting feature of the present results from the experiments that tested the effect of NBTI or of meclonazepam was 
their ability to increase considerably the amount of rebound ACh formed. It is possible that this effect is unrelated to their ability to inhibit nucleoside uptake. However, considering that these two drugs are structurally quite different and that their only known similarity is their inhibition of the NBTI-sensitive nucleoside transporter, it might be that their effect to increase rebound $\mathrm{ACh}$ is based on this characteristic. If so, the result suggests that blockade of the NBTI-sensitive transporters shunts adenosine toward the NBTI-resistant sites and, in this way, provides more adenosine to whatever mechanism is responsible for its ability to increase ACh synthesis. The present result showing dipyridamole to block the NBTI-induced increase of rebound $\mathrm{ACh}$ is compatible with this notion. There are two interesting corollaries to this: first, the endogenous adenosine available to the preganglionic nerve terminals for transport by the NBTI-resistant carriers must be subsaturating; second, the two types of nucleoside transporters must be in close enough apposition to each other for the postulated shunting of adenosine to be functional. With respect to the last point, the two types of nuclcoside transporters are considered to coexist on certain cell types (Belt, 1983ab; Plagemann and Wohlheuter, 1985), including neurons (Lee and Jarvis, 1988ab; Shank and Baldy, 1990; Jones and Hammond, 1992). If this coexistence were to be so for the preganglionic nerve endings, it implies that the intracellular accumulation of adenosine that increases ACh synthesis would have to be restricted to a site close to the NBTIresistant carriers; otherwise, transport through the NBTI-sensitive transporters would be expected to have the same effect, as it is unlikely that any intracellular process could distinguish adenosine on the basis of its site of entry. Thus, it seems more likely that the NBTI-sensitive uptake is not associated with preganglionic nerve endings but on structures close enough to them to affect the synaptic concentration of adenosine. Furthermore, the presence of adenosine transporters not linked to the synthesis of rebound $\mathrm{ACh}$ may represent potential targets for rcgulatory mechanisms to determine synaptic adenosine concentration, and thus, govern the extent of potentiation of transmitter stores depending upon the strength and duration of the conditioning stimulation.

We have previously speculated that one possible source of synaptic adenosine in the ganglia could be from ATP co-stored with ACh in synaptic vesicles (Tandon and Collier, 1993). However, the results discussed above suggest that adenosine efflux in the present study likely occurred after, not during, the conditioning stimulation, that is, when $\mathrm{ACh}$ output had returned to basal levels. Thus, the endogenous synaptic adenosine does not appear to originate from vesicular stores co-released with ACh. Doubtless, there are other mechanisms that might allow adenosine into the synaptic cleft that can be considered, including the nucleoside transporters themselves, which are able to operate in reverse direction (see review by Geiger and Nagy, 1990). However, the simplest interpretation of our previous results with exogenous adenosine application suggests that adenosine uptake into nerve terminals preceded activation of $\mathrm{ACh}$ synthesis, so it would be unlikely that, in the context of the present experiments, the same presynaptic sites that import adenosine are involved first with its export into the synapse. Thus, a postsynaptic source of adenosine appears to be more likely and there is evidence for this in other systems (Wolinsky and Patterson, 1985), as well as sympathetic ganglia (Rubio et al., 1988). Adenosine might act as a diffusible retrograde signal to accelerate $\mathrm{ACh}$ synthesis; there is appreciable interest in the involvement of retrograde transmission in activity-induced synaptic plasticity (see review by Jessell and Kandel, 1993).

This notion leads to the question of what signals adenosine release if it is to act as a retrograde transmitter. The role of $\mathrm{ACh}$, the principal neurotransmitter, as this signal is unlikely. First, neither muscarinic (Bourdois et al., 1974) nor nicotinic (Collier et al., 1983) receptor activation appears to be obligatory for the formation of rebound $\mathrm{ACh}$. Second, the rate of $\mathrm{ACh}$ output evoked by $16 \mathrm{~Hz}$ stimulation is not different from that at $64 \mathrm{~Hz}$ (Birks and MacIntosh, 1961), yet the synthesis of rebound $\mathrm{ACh}$ is clearly frequency dependent (Bourdois et al., 1974; Birks, 1977). Alternate transmitters, such as the peptides present in synaptic boutons of sympathetic ganglia (for review, see Elfvin et al., 1993) may be more likely candidates, especially when it is considered that high-frequency stimulation is generally a prerequisite for peptide release (for reviews, see Bartfai et al., 1988; Kupfermann, 1991), just as it is for the initiation of the rebound phenomenon.

Overall, these results support a role for endogenous adenosine acting as a signal to activate the synthesis of rebound $\mathrm{ACh}$; whether it is the only potentiating factor involved in the posttetanic phenomenon is not clear.

\section{Compartmentalization and release of rebound $A C h$}

Kinetic analysis of transmitter output from ganglia suggests that the $\mathrm{ACh}$ release behaves as if it is stored in at least two compartments: a smaller readily releasable pool, and a larger reserve pool (Birks and MacIntosh, 1961). The compartmentalization of rebound $\mathrm{ACh}$ in this scheme has remained somewhat ambiguous. Bourdois et al. (1974) suggested that the rebound $\mathrm{ACh}$ incorporated into the reserve pool because conditioned ganglia exhibited an increased output of ACh only after a significant lag period. However, Birks (1977) reported that evoked release following the synthesis of the extra $\mathrm{ACh}$ was proportional to the increase in total transmitter stores. Furthermore, Collier et al. (1983) radiolabeled rebound $\mathrm{ACh}$ by presenting conditioned ganglia with ${ }^{3} \mathrm{H}$-choline during the rest period; when $\mathrm{ACh}$ release was evoked by subsequent preganglionic stimulation, the specific activity of the released $\mathrm{ACh}$ matched that of the tissue $\mathrm{ACh}$, indicating that rebound $\mathrm{ACh}$ had mixed with preexisting stores prior to its discharge.

We extended these studies by measuring evoked $\mathrm{ACh}$ release following conditioning in the absence or presencc of vesamicol, a drug that prevents the accumulation of $\mathrm{ACh}$ by vesicles (for review, see Parsons et al., 1993) and allows the release of only about $14 \%$ of the total ganglionic ACh stores upon stimulation, a fraction that is considered to represent the readily releasable pool of transmitter (Collier et al., 1986; Cabeza and Collier, 1988; Prado et al., 1992). In the absence of vesamicol, the initial ACh output from conditioned ganglia was increased in proportion to the amount of rebound $\mathrm{ACh}$ accumulated. However, ACh release remained potentiated for the duration of stimulation, whereas the ACh stores had returned to control levels by the end of stimulation. Therefore, while rebound $\mathrm{ACh}$ may have been the source of ACh initially, some other mechanism maintained release at an elevated level. It is not clear whether this longer-lasting potentiation of release is related to an effect of adenosine or to some other simultaneously occurring process. For instance, it may be related to a similar phenomenon observed by Briggs et al. (1985) after a short tetanus, which did not require increased transmitter content. Alternatively, adenosine has been reported to induce a persistent increase in glu- 
tamate release from hippocampal slices, an action that is not mimicked by $A_{1}$ or $A_{2}$ receptor agonists (Nishimura et al., 1990, 1992; Okada et al., 1992); it is possible that a similar effect of adenosine is apparent in ganglia following the conditioning paradigm of the present experiments.

In the presence of vesamicol, conditioned ganglia released the same amount of $\mathrm{ACh}$ as their unconditioned controls, suggesting that the less readily releasable compartment adapts to incorporate the extra $\mathrm{ACh}$ and the size of the readily releasable compartment remains the same. The increased rate of $\mathrm{ACh}$ output from conditioned ganglia in the absence of vesamicol is presumably the result of an increased rate of mobilization from the lcss readily releasable pool. As rebound $\Lambda \mathrm{Ch}$ mixes with the preexisting stores (Collier et al., 1983), it would appear that, although only the size of the reserve pool is modified, rebound $\mathrm{ACh}$ takes part in the tonic exchange of $\mathrm{ACh}$ molecules between the reserve and readily releasable compartments. Similarly, our results using exogenous adenosine suggested also that the extra ACh synthesized in adenosine's presence was incorporated into, and increased release from, the $\mathrm{ACh}$ pool that requires mobilization for release (Tandon and Collier, 1993).

\section{References}

Bartfai T, Iverfeldt K, Fisone G, Serfözö P (1988) Regulation of the release of coexisting neurotransmitters. Annu Rev Pharmacol Toxicol $28: 285-310$

Belt JA (1983a) Heterogeneity of nucleoside transport in mammalian cells. Two types of transport activity in L1210 and other cultured neoplastic cells. Mol Pharmacol 24:479-484.

Belt JA (1983b) Nitrobenzylthioinosine-insensitive uridine transport in human lymphoblastoid and murine leukemia cells. Biochem Biophys Res Commun 110:417-423.

Birks RI (1977) A long-lasting potentiation of transmitter release related to an increase in transmitter stores in a sympathetic ganglion. J Physiol (Lond) 271:847-862.

Birks RI (1978) Regulation by patterned preganglionic neural activity of transmitter stores in a sympathetic ganglion. J Physiol (Lond) 280: 559-572.

Birks RI, Fitch SJG (1974) Storage and release of acetylcholine in a sympathetic ganglion. J Physiol (Lond) 240:125-134.

Birks RI, Maclntosh FC (1961) Acetylcholine metabolism of a sympathetic ganglion. Can J Biochem Physiol 39:787-827.

Bourdois PS, McCandless DL, MacIntosh FC (1974) A prolonged after-effect of intense synaptic activity on acetylcholine in a sympathetic ganglion. Can J Physiol Pharmacol 53:155-165.

Briggs CA, MCAfee DA, McCaman RF (1985) Long-term potentiation of synaptic acetylcholine release in the superior cervical ganglion of the rat. J Physiol (Lond) 363:181-190.

Cabeza R, Collier B (1988) Acetylcholine mobilization in a sympathetic ganglion in the presence and absence of 2-(4-phenylpiperidino)cyclohexanol (AH5183). J Neurochem 50:112-121.

Collier B, Kwok YN (1982) Superior cervical ganglion: chemical considerations. In: Progress in cholinergic biology: model cholinergic synapses (Hanin I, Goldberg. AM, eds), pp 169-190. New York: Raven.

Collier B, Kwok YN, Welner SA (1983) Increased acetylcholine synthesis and release following presynaptic activity in a sympathetic ganglion. J Neurochem 40:91-98.

Collier B, Welner SA, Ričný J, Araujo DM (1986) Acetylcholine synthesis and release by a sympathetic ganglion in the presence of 2-(4phenylpiperidino)cyclohexanol (AH5183). J Neurochem 46:822-830.

Deuticke B, Duhm J, Gerlach E (1964) Beeinflussung der monosaccharid-permeabilität des menschen-erythrocyten durch eine pyrimido-pyrimidin-verbindung. Pfluegers Arch 280:275-280.

Elfvin L-G, Lindh B, Hökfelt T (1993) The chemical neuroanatomy of sympathetic ganglia. Annu Rev Neurosci 16:471-507.

Feldberg W (1943) Synthesis of acetylcholine in sympathetic ganglia and cholinergic nerves. J Physiol (Lond) 101:432-445.

Fonnum $F(1969)$ Isolation of choline esters from aqueous solution by extraction with sodium tetraphenylboron in organic solvents. Biochem J 113:291-298.

Friesen AJD, Khatter JC (1971) The effect of preganglionic stimulation on the acetylcholine and choline content of a sympathetic ganglion. Can J Physiol Pharmacol 49:375-381.

Geiger JD, Nagy JI (1990) Adenosine deaminase and $\left[{ }^{3} \mathrm{H}\right]$ nitrobenzylthioinosine as markers of adenosine metabolism and transport in central purinergic systems. In: Adenosine and adenosine receptors (Williams M, ed), pp 225-288. Clifton, NJ: Humana.

Goldberg AM, McCaman RE (1973) The determination of picomole amounts of acetylcholine in mammalian brain. J Neurochem 20:1-8.

Jessell TM, Kandel ER (1993) Synaptic transmission: a bidirectional and self-modifiable form of cell-cell communication. Cell $72 /$ Neuron $10: 1-30$.

Jones KW, Hammond JR (1992) Heterogeneity of ['H]dipyridamole binding to CNS membranes: correlation with $\left[{ }^{3} \mathrm{H}\right]$ nitrobenzylthioinosine binding and $\left[{ }^{3} \mathrm{H}\right]$ uridine influx studies. $\mathbf{J}$ Neurochem 59:1363-1371.

Kahlson G, MacIntosh FC (1939) Acetylcholine synthesis in a sympathetic ganglion. J Physiol (Lond) 96:277-292.

Kibjakow AW (1933) Über humorale Übertrazung der Erregung von einem Neuron auf das andere. Pfluegers Arch Physiol 232:432-443.

Kupfermann I (1991) Functional studies of cotransmission. Physiol Rev 71:683-732.

Lee CW, Jarvis SM (1988a) Kinetic and inhibitor specificity of adenosine transport in guinea pig cerebral cortical synaptosomes: evidence for two nucleoside transporters. Neurochem Int 12:483-492.

Lee CW, Jarvis SM (1988b) Nucleoside transport in rat cerebral cortical synaptosomes. Evidence for two types of nucleoside transporters. Biochem J 249:557-564.

Nishimura S, Mohri M, Okada Y, Mori Y (1990) Excitatory and inhibitory effects of adenosine on the neurotransmission in the hippocampal slices of guinea pig. Brain Res. 525:165-169.

Nishimura S, Okada Y, Amatsu M (1992) Post-inhibitory excitation of adenosine on neurotransmission in guinea pig hippocampal slices. Neurosci Lett 139:126-129.

Okada Y, Sakurai T, Mori M (1992) Excitatory effect of adenosine on neurotransmission is due to increase of transmitter release in the hippocampal slices. Neurosci Lett 142:233-236.

O'Regan S, Collier B (1981) Factors affecting choline transport by the cat superior cervical ganglion during and following stimulation, and the relationship between choline uptake and acetylcholine synthesis. Neuroscience 6:511-520.

Parsons SM, Prior C, Marshall IG (1993) Acetylcholine transport, storage and release. Int Rev Neurobiol 35:279-390.

Plagemann PGW, Wohlheuter RM (1985) Nitrobenzylthioinosinesensitive and -resistant nucleoside transport in normal and transformed cells. Biochim Biophys Acta 816:387-395.

Prado MAM, Gomez MV, Collier B (1992) Mobilization of the readily releasable pool of acetylcholine from a sympathetic ganglion by tityustoxin in the presence of vesamicol. J Neurochem 59:544-552.

Rosenblueth A, Lissák K, Lanari A (1939) An explanation of the five stages of neuromuscular and ganglionic synaptic transmission. Am J Physiol 128:31-44

Rubio R, Bencherif M, Berne RM (1988) Release of purines from postsynaptic structures of amphibian ganglia. J Neurochem 51:17171723.

Shank RP, Baldy WJ (1990) Adenosine transport by rat and guinea pig synaptosomes: basis for differential sensitivity to nucleoside transporters. J Neurochem 55:541-550.

Tandon A, Collier B (1991) A possible role for endogenous adenosine at sympathetic ganglia. J Neurochem [Suppl] 57:S155A.

Tandon A, Collier B (1993) Increased acetylcholine content induced by adenosine in a sympathetic ganglion and its subsequent mobilization by electrical stimulation. J Neurochem 60:2124-2133.

Welner SA, Collier B (1984) Uptake, metabolism and releasability of ethyl analogues of homocholine by rat brain. J Neurochem 43:11431151 .

White TD (1988) Role of adenine compounds in autonomic neurotransmission. Pharmacol Ther 38:129-168.

Woffendin C, Plagemann PGW (1987) Interaction of $\left[{ }^{3} \mathrm{H}\right]$ dipyridamole with the nucleoside transporters of human erythrocytes and cultured animal cells. J Membr Biol 98:89-100.

Wolinsky EJ, Patterson PH (1985) Potassium-stimulated purine release by cultured sympathetic neurons. J Neurosci 5:1680-1687. 